\title{
WILLIAM ROTCH BULLARD, JR., 1926-1972
}

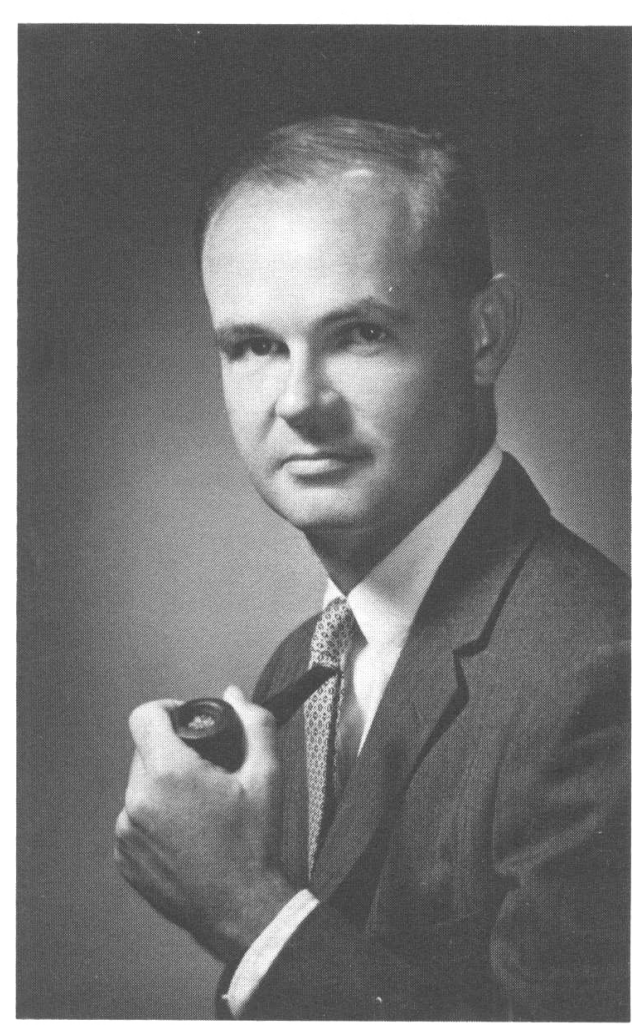

WILLIAM R. BULLARD, JR.

WILLIAM ROTCH BULLARD, JR., was born on June 4, 1926, in Boston, Massachusetts, the second son of William Rotch Bullard and Hilda (Greenleaf) Vickery. He died on May 21, 1972, at South Dartmouth, Massachusetts. Devoted to American archaeology, he had a wide professional and field experience, especially in the southwestern United States and mesoamerican areas. His death at midpoint in a productive career is a substantial loss in the ranks of Americanist scholars.

Bullard's preparatory education was at the Berkshire School in Sheffield, Massachusetts. He entered Harvard as an undergraduate with the class of 1947; however war service in Japan and Korea interrupted his studies so that his actual graduation was not until 1950, when he received the A.B. degree, cum laude. After that, he continued at Harvard with graduate work in anthropology. His formal course requirements were completed early in the 1950's, but he interspersed classroom work with frequent semesters devoted to field research. He served as field assistant to J. O. Brew, then Director of the Peabody Museum, in excavation and survey programs in the Southwest. In Yucatan, and then in British Honduras, he was employed by the Carnegie Institution and by me in Maya field research. He also found time during this active decade of the 1950's to do 1 summer's field stint in Alaska and another in South Dakota. By the time he received his Ph.D. at Harvard, on a thesis topic in southwestern archaeology, submitted in 1960, Bullard was a fully trained professional archaeologist.

Bullard's formal professional employment, in academic and museum positions, began in 1960 with a 1 yr lectureship in anthropology at Harvard. Immediately after this, he joined the staff of the Royal Ontario Museum as Field Director of their British Honduras Archaeological Project, a position he held from 1961 to 1963. In 1963 he became Assistant Director of the Peabody Museum at Harvard and continued in this post until 1968. He was a part-time lecturer in anthropology at Franklin Pierce College in New Hampshire in 1968 before becoming, later in that year, Associate Curator and Chairman of the Department of Social Sciences of the Florida State Museum (University of Florida) in Gainesville, a position he held until his death. Bullard's professional society affiliations included the American Anthropological Association (Fellow), the Society for American Archaeology (Member and Chairman, Nominating Committee for 1970), and the Florida Anthropological Society (Member).

Bullard's southwestern thesis was published as The Cerro Colorado site and pithouse architecture in the southwestern United States prior to A.D. 900 (see below). In it he entered directly into the controversy then raging over Mogollon origins and Mogollon-Anasazi relationships. Bullard was a partisan in this debate, seeing Mogollon culture as essentially derivative from northern Basketmaker centers; but even his opponents in the argument gave him high marks for the 
excellence of his field reporting and careful presentation of results, and the monograph stands as one of the pillars of hard knowledge for the region and period. Bullard was not only an extremely skillful and sensible excavator, but he combined these qualities with an ability to write crystal-clear English prose.

The Cerro Colorado work was done in the 1950's, and the report appeared in 1962; but well before the latter date Bullard was completely involved in Maya archaeology. At Mayapan he had his first taste of Maya bush settlement pattern survey, an investigation which he later published as an account of household "property walls" within that Postclassic metropolis (1953, 1954). From 1954 through 1956, I was fortunate enough to have him along as my principal assistant at Barton Ramie, in the Belize Valley, where he mapped the more than 260 small structures or "house mounds" and had a large share in the excavations of these (see Willey and others 1965). His intellectual interests in the Maya "house mound" and overall Maya lowland settlement pattern problem date from this time. In our arguments and discussions in the Barton Ramie field camp, Bullard always took the position that we should move out from our relatively tame preoccupation with the excavation and dating of a single set of "house mounds" and their levels and tackle the problem in the toughest way by surveying the heavy British Honduras and Peten jungles well beyond the peripheries of the ceremonial centers. While seeing the validity of much of his argument, I was somewhat less enthusiastic than he about the possibilities of plunging forthwith into the jimba and lianas so he was forced to wait to do this on his own after the close of the Barton Ramie project. He set out with a guide, muleteers, 2 workmen, and minimal cargo to explore along the half-grown-over chicle trails, and between these trails, in search of the low Maya platform tumuli that usually cannot be seen unless one is standing immediately upon them. This work took him into the very heart of the great rainforests, in the northeast Peten, in what has come to be known as the "core area" of southern Lowland Maya civilization. It was first reported upon in his most important short article, "Maya settlement patterns in the northeastern Peten, Guatemala," in 1960. From this basic field study-which also moved in some interpretive directions-Bullard went on to his more broadly oriented archaeological-anthropological article, "Settlement pattern and social structure in the southern Maya lowlands during the Classic period" (1966).

In 1960 Bullard married Mary Ricketson (who survives him), daughter of Oliver G. Ricketson, Jr., and Edith Bayles Ricketson, both Maya archaeologists of Uaxactun fame. Mary shared Bill's archaeological interests, both in the field and in the laboratory, and these interests and their work together are represented in the several monographs (on San Estevan, Baking Pot, and Topoxté) brought out under the aegis of either of the Royal Ontario Museum or the Peabody Museum. His last explorations were at Macanché, in the Peten. In this investigation, which was completed in the field although never published, Bullard was pursuing research leads which began with his excavations at Postclassic Topoxté. He was especially interested (as all Peten Mayanists are) in determining the degree and duration of Postclassic occupation in that region, however minimal, after the classic Maya ninth century collapse; and he had made some substantial progress on this problem by his definition of a Peten Postclassic ceramic tradition (see below, publication expected for 1972). In this connection, his contribution to the Santa Fe symposium on the "Classic Maya collapse," held in the fall of 1970 , was of prime importance.

As a person, William Bullard was a man of great integrity, grit, and determination. In this he was true to a long line of New England forbears, one of whom participated in the Boston Tea Party while another, a sea captain and a whaler, lost his leg but not the command of his ship in the tradition of Melville's Ahab. Bullard was of the same stern stuff; yet this inner strength and firmness was moderated by true modesty, simplicity of manner, and good-humored wit. Those of us who were closely associated with him as his friends are more deeply saddened by his death than such a conventional statement as this can possibly convey. 
Bibliography of William R. Bullard, Jr.

1952a Boundary walls of Mayapan. Carnegie Institution of Washington, Year Book 51:244-247.

1952b Residential property walls at Mayapan. Carnegie Institution of Washington, Current Reports 3, Vol. $1: 36-45$.

1953 Property walls at Mayapan. Carnegie Institution of Washington, Year Book 52:258-264.

1954 Boundary walls and house lots at Mayapan. Carnegie Institution of Washington, Current Reports 13, Vol. $1: 234-253$.

1955 (With G. R. Willey and J. B. Glass) The Maya community of ancient times. Archaeology 8:18-25.

1956a (With F. E. Cassidy) Sections in Pipeline archaeology, reports of salvage operations in the Southwest on El Paso Natural Gas Co. projects, 1950-1953, edited by F Wendorf. Laboratory of Anthropology and Museum of Northern Arizona.

1956b (With G. R. Willey) The Melhado site, a house mound group in British Honduras. American Antiquity 22:29-44.

1960a Prehistoric Maya settlements in Peten, Guatemala. American Philosophical Society, Yearbook 1959, pp. 499-502.

1960 b (With G. R. Willey, A. L. Smith, and J. Graham) Altar de Sacrificios, a prehistoric Maya crossroads. Archaeology 13:110-117. [Published in Spanish in Antropologia e Historia de Guatemala 12(1), 1960.]

1960c Maya settlement patterns in northeastern Peten, Guatemala. American Antiquity 25:355-372.

1961 a Archaeological investigation of the Maya ruin of Topoxté, Peten, Guatemala. American Philosophical Society, Year Book 1960, pp. 551-554.

1961 b (With G. R. Willey) Altar de Sacrificios, mapa preliminar y resumen de las excavaciones. In Estudios de Cultura Maya, Vol. 1, pp. 81-85. Mexico.

1962 The Cerro Colorado site and pithouse architecture in the southwestern United States prior to A.D. 900. Peabody Museum, Harvard University, Papers 44(2).

1963a A progress report of the British Honduras expedition. Royal Ontario Museum, Division of Art and Archaeology, Annual pp. 10-16.

1963b A unique Maya shrine site on the mountain pine ridge of British Honduras, American Antiquity 29:98-99.

$1963 \mathrm{c}$ Review of Incidents of travel in Yucatan, by John Lloyd Stephens, edited by V. W. von Hagen. American Antiquity 28:571-572.

1964 Settlement pattern and social structure in the southern Maya lowlands during the Classic period. $X X X V$ Congreso Internacional de Americanistas, Mexico, 1962, Actas y Memorias 1:279-287. [Reprinted in Ancient Mesoamerica, selected readings, edited by John A. Graham. Palo Alto, 1966.]

1965a Late Classic finds at Baking Pot, British Honduras. Royal Ontario Museum, Art and Archaeology, Occasional Paper 8.

1965b Stratigrahpic excavations at San Estevan, Northern British Honduras. Royal Ontario Museum, Art and Archaeology, Occasional Paper 9.

$1965 \mathrm{c}$ (With G. R. Willey) Prehistoric settlement patterns in the Maya lowlands. In Handbook of Middle American Indians, Vol. 2, pp. 360-377. Austin.

1965d (With G. R. Willey and others) Prehistoric Maya settlements in the Belize Valley. Peabody Museum, Harvard University, Papers 54.

1965 e Ruinas ceremoniales mayas en el curso inferior del Rio Lacantun, Mexico. In Estudios de Cultura Maya, Vol. 5, pp. 41-51. Mexico.

1967 Review of The rise and fall of Maya civilization (2nd ed.), by J. E. S. Thompson, and The Maya, by M. D. Coe. American Journal of Archaeology 71:326-327.

1968 Review of The book of Chilam Balam of Chumayel, by Ralph L. Roys (2nd ed.). Archaeology $21: 222-223$.

1969 Review of Jaina, La Casa En El Agua, by Roman Piña Chan. American Journal of Archaeology 73:394-395.

1970a Review of Machaquila, by Albert Lisi. Archaeology 23:259.

$1970 \mathrm{~b}$ Review of Tikal, A handbook of the Ancient Maya ruins, by W. R. Coe. Archaeology 23:259-260.

1970c Review of Edzna, Campeche, Mexico: settlement patterns and monumental architecture, by $\mathrm{G}$. F. Andrews. American Antiquity 35:401-402.

$1970 d$ (Editor) Monographs and papers in Maya archaeology. Peabody Museum, Harvard University, Papers 61.

1970e Topoxté, a Postclassic site in Peten, Guatemala. Peabody Museum, Harvard University, Papers $61: 245-307$.

$1970 \mathrm{f}$ Review of $A$ comparison of formative cultures in the Americas, by James A. Ford. Florida Historical Quarterly 49(2):165-166.

$1970 \mathrm{~g}$ Review of The Maya Chontal Indians of Acalan-Tixchel, by F. V. Scholes and R. L. Roys (reprint 1968). Archaeology 23:92-93.

1971a Review of The archaeological use and distribution of mollusca in the Maya lowlands, by E. W. Andrews, IV. American Anthropologist 73:921-922.

$1971 \mathrm{~b}$ Review of The prehistory of the Tehuacan Valley, Vol. 3: Ceramics, by MacNeish, Peterson, and Flannery. Archaeology 24:370. 
Publication expected in 1972:

Postclassic culture in central Peten and adjacent British Honduras, in volume of papers from The Maya Collapse Symposium to be published by The School of American Research, Santa Fe. 